\title{
Ovulation and initial rearing of Steindachneridion parahybae (Siluriformes: Pimelodidae) larvae from different accumulated thermal units
}

\author{
Renan Yoshiharu Okawara ${ }^{1} \cdot$ Eduardo Antônio Sanches $^{2} \cdot$ Danilo Caneppele $^{3}$. \\ Danielle Zanerato Damasceno $^{4} \cdot$ Elizabeth Romagosa $^{1}$
}

Received: 6 October 2014/Revised: 6 March 2015/Accepted: 7 March 2015/Published online: 1 April 2015

(C) The Ichthyological Society of Japan 2015

\begin{abstract}
Steindachneridion parahybae is an endemic catfish to the Paraiba do Sul river basin classified as critically endangered. Little is known about the reproductive management of this species in captivity, adopting for this practice empirical measures. The objectives were to: (1) determine suitable Accumulated Thermal Units (ATUs) at the moment of ovulation in January 2011 and 2012; (2) follow initial larvae rearing in 180, 240 and 300 degreehours. Nine selected females were divided into three experimental groups of three specimens each (replications), distributed at pre-established times: 140, 160, 180, 200, 220, 240, 260, 280 and 300 degree-hours. The females were induced with two doses of 0.5 and $5.0 \mathrm{mg} \mathrm{kg}^{-1}$ of dry carp pituitary, respectively, at an interval of $12 \mathrm{~h}$. The extruded oocytes were kept at average water temperature of $22.35 \pm 0.53{ }^{\circ} \mathrm{C} \quad(2011)$ and $21.88 \pm 0.15^{\circ} \mathrm{C}$ (2012). Fertilization and hatching rates were: 84.22 and $71.33 \%$ at 174.2 ATUs in 2011, and $55.58 \%$ and $36.13 \%$ at 251.0 ATUs in 2012. In January 2012, 900 larvae were distributed in three replications (triplicate) consisting of 100 larvae each and were fed: 120 (second day), 300 (third-
\end{abstract}

Renan Yoshiharu Okawara

renanok@hotmail.com

Elizabeth Romagosa

e.romagosa@uol.com.br

1 Fishery Institute, APTA, SAA, SP. Avenida Francisco Matarazzo, 455, Sao Paulo, SP 05001-970, Brazil

2 State University of Sao Paulo, Registro Experimental Campus, Registro, SP, Brazil

3 Sao Paulo Energy Company (CESP), Hydrobiology and Aquaculture Station, Paraibuna, SP, Brazil

4 State University of Sao Paulo, UNESP Aquaculture Center, Jaboticabal, SP, Brazil fourth day), 600 (fifth-eighth day), and 1,200 Artemia salina nauplii per larva (ninth-15th day), six times a day. The larvae exhibited mean weight of $523.67 \pm 54.42$, $496.67 \pm 61.98$ and $475.00 \pm 22.83 \mathrm{mg}$, length of $17.75 \pm 0.57,17.58 \pm 0.51$ and $17.45 \pm 0.25 \mathrm{~cm}$ and survival of $63.95 \pm 24.50,71.71 \pm 6.61$ and $79.65 \pm$ $0.82 \%$, when hatched in 180, 240 and 300 ATUs, respectively. The larvae body parameters did not show significant differences at these degree-hours.

Keywords Endangered fish species - Degree-hours · Larviculture $\cdot$ Induced spawning $\cdot$ Temperature

\section{Introduction}

Steindachneridion parahybae is an endemic catfish to the Paraíba do Sul river basin which has been commercially exploited since the 1950s (Machado and Abreu 1952). That basin crosses three states of Brazil-Rio de Janeiro, Minas Gerais and São Paulo-where its ichthyofauna is subject to the impacts of anthropogenic activities (i.e., sand extraction, livestock, subsistence agriculture, fishing, dams, chemicals in agriculture, removal of riparian forests and occupation of tributaries sub-basins) (Hilsdorf and Petrere Jr 2002). The scale of these impacts on the fauna led $S$. parahybae to be included in the list of endangered fish species with a critical situation in the Paraíba do Sul river basin (Ministério do Meio Ambiente 2008).

According to Caneppele et al. (2009), studies on the reproductive mechanisms of native species in impacted hydrographic basins are rare. The spawning season of $S$. parahybae occurs from late November until March, and its feeding habit is mainly carnivorous (ichthyophagous). Their endangered status (Rosa and Lima 2005) makes any 
biological study extremely laborious, especially during sample collection stages. Therefore, the present difficulty of capturing the species may contribute to the paucity of information about this species, which is at risk of becoming extinct without being fully described. Information on characterization of the gametes and the reproductive management of $S$. parahybae during the process of artificial fertilization has been obtained by the application of reproductive biotechnology, in captivity (Caneppele, unpublished data). Those practices directly contribute to the success of spawning (Sanches et al. 2009), promoting maximum fertilization, and subsequently, the normal development of the embryo (Brooks et al. 1997; Bobe and Labbé 2010; Santos et al. 2013).

Many aspects of fish life are controlled by different levels of environmental and biological factors, such as temperature, food availability, pollution, predation or a combination of these factors (Gadomski and Caddell 1996; Kupren et al. 2011). It is known that one of the climatic factors which stimulates the artificial spawning of fish kept in captivity is water temperature, which is determinant in the production of satisfactory gametes and progeny (Romagosa 2010). Temperature changes accelerate or delay gamete maturation (Vikingstad et al. 2008) and may affect the time and course of spawning (Hilder and Pankhurst 2003), the quality and size of eggs (King et al. 2003; Kucharczyk et al. 2014) as well as the larvae growth, development and survival rates (Kujawa et al. 1997; Kupren et al. 2011).

Therefore, the evolution of the thermal history of the broodfish is followed (Ceccarelli et al. 2000), where the values of water temperature after the second hormonal injection in the females (first one in the males, if necessary) and the moment of oocyte release (ovulation) is variable, because they depend on the different needs of each species, as well as the seasonal variations imposed on the reproduction laboratories. Consequently, the degree-hour is calculated. The degree-hour, also called accumulated thermal unit (ATU), is the interval between the time (hours) multiplied by the water temperature $\left({ }^{\circ} \mathrm{C}\right)$, where the degree-hour indicates the moment of stripping or manipulation for the gamete release. According to Ceccarelli et al. (2000), the estimate of that interval allows us to reduce the handling of the broodfish, reflecting in the productive performance of the eggs and larvae.

As a consequence of the reproductive success, there is the larviculture stage, where the largest losses in the productive process occur, making it necessary to use satisfactory management techniques (Romagosa 2010). Those losses are associated with the initial feeding of the larvae and, in some species, with the aggressive behavior exhibited soon after the absorption of the yolk sac and then the search for exogenous food. Understanding these stages guarantees survival, mainly in a culture environment (Landines 2003).

Considering the condition of $S$. parahybae in the wild, it was decided to evaluate the effect of temperature (focusing on ATUs) on the ovulation in two reproductive cycles2011 and 2012 - and the initial development of the larvae from different ATUs (180, 240 and 300 degree-hours) in 2012.

\section{Material and methods}

Breeding management. The experiment was carried out in January 2011 and January 2012 at the Hydrobiology and Aquaculture Station of the Sao Paulo Energy CompanyCESP, in the town of Paraibuna, São Paulo, Brazil $\left(23^{\circ} 24.888^{\prime} \mathrm{S}, 45^{\circ} 35.991^{\prime} \mathrm{W}\right.$ and $640 \mathrm{~m}$ altitude), in accordance with the Guidelines for Animal Experimentation established by the Brazilian College for Animal Experimentation (COBEA).

The selected specimens of Steindachneridion parahybae (F1) were part of a batch produced from 33 wild broodstocks in December 2003 (Caneppele et al. 2009). The fish, kept in $200 \mathrm{~m}^{3}(20 \times 10 \times 1 \mathrm{~m})$ earthen ponds, were fed commercial feed (40\% C.P.) offered twice a day, at 0800 hours and 1700 hours, seven days a week, at a proportion of $3 \%$ of total biomass. Broodstock that had reached advanced stages of maturation were selected for the experiments. Females were selected that had a slightly bulging abdomen and ovulated ova that could be stripped when pressure was applied to the abdomen. Males were chosen according to the quantity of milt released after gentle pressure on the abdomen. They were then electronically identified (tags), weighed, measured (Table 1), handled in accordance with the ethical principles established by Van Zutphen et al. (2001) and transferred to $175 \mathrm{~L}$ aquaria $(75 \times 43 \times 54 \mathrm{~cm})$ under constant aeration.

To determine the degree of development, the intra-ovarian oocytes were sampled with a plastic catheter (human

Table 1 Number of specimens of Steindachneridion parahybae and mean values of weight, length and standard deviation during the experiment

\begin{tabular}{lll}
\hline Parameters & Years \\
\cline { 2 - 3 } & January 2011 & January 2012 \\
\hline Number of females & 9 & 9 \\
$\mathrm{TW} \pm \mathrm{sd}(\mathrm{g})$ & $927.67 \pm 137.19$ & $855.56 \pm 113.04$ \\
$\mathrm{TL} \pm \mathrm{sd}(\mathrm{cm})$ & $44.44 \pm 2.07$ & $44.17 \pm 2.14$ \\
Number of males & 1 & 1 \\
TW $(\mathrm{g})$ & 940.00 & 1010.00 \\
$\mathrm{TL}(\mathrm{cm})$ & 45.00 & 47.00 \\
\hline
\end{tabular}

$T W$ Total weight; $T L$ total length; $s d$ standard deviation 
urethral catheter) before the first hormonal dose (first sample) and at the moment of ovulation (second sample), according to the technique recommended by Romagosa et al. (1990). Females (Table 1) were selected using the following criteria: flowing easily, mainly yellowish, homogeneous size and size composition analyses (Romagosa et al. 2001). Approximately, 100 oocytes were measured and preserved in Gilson solution (Simpson 1951) for 30 minutes to measure the diameter with a stereomicroscope (Obj. 2x; Oc. 10x). These measures were used to construct the graphs of frequency distribution.

Induced spawning assay. Based on the distribution of oocyte diameter at the first sampling, 18 females (nine females in each year) were chosen and received an injection of dry carp pituitary diluted in saline $(0.6 \% \mathrm{NaCl})$, in two doses $\left(0.5\right.$ and $\left.5.0 \mathrm{mg} \mathrm{kg}^{-1}\right)$ : the first one with $10 \%$, and the second one 12 hours later with the remainder (Caneppele et al. 2009). Intramuscular injections were given on the dorsal region of the fish. The females (nine females/year) were then distributed in a completely randomized experimental design (CRD), and three experimental groups were formed with three specimens each (in triplicate), distributed at predetermined time intervals of 20 degree-hours (sum of water temperature versus time). The oocytes were again sampled before the second hormonal injection on. In the females of Groups I (140 degreehours) and II (160 degree-hours), ovulation did not occur and the oocyte sample was removed by cannulation (Table 2). Only the 180 degree-hours group (Group III) was removed by stripping in both cycles (Table 2).

According to the established degree-hours (Table 2), each sample of stripped oocytes was individually fertilized by the dry method (Leonardo et al. 2004) and taken to experimental hatcheries $(1.5 \mathrm{~L})$ with mean water temperature of $22.35 \pm 0.53{ }^{\circ} \mathrm{C}(2011)$ and $21.88 \pm 0.15{ }^{\circ} \mathrm{C}$ (2012). The semen samples $(100 \mu \mathrm{l})$ were collected by abdominal massage of the cavity of the fish in graduated tubes $(0.1 \mathrm{~mL})$.

Water quality. The water quality parameters were monitored with the aid of a multi-analyzer instrument (Horiba U50): temperature $\left({ }^{\circ} \mathrm{C}\right), \mathrm{pH}$ and concentration of dissolved oxygen $\left(\mathrm{mg} \mathrm{L}^{-1}\right)$ in the aquaria, experimental hatcheries (until the moment of larvae hatching) and the trays. The values of these parameters in 2011 and 2012 were submitted to the Mann-Whitney nonparametric test, at a $5 \%$ level of significance $(P<0.05)$. To that end, the year was considered as an independent variable.

Fertilization and incubation. In the present study, the fertilization rate was estimated after the closure of the blastopore, as recommended by Bobe and Labbé (2010). Eleven hours after fertilization, the eggs were siphoned and counted from each experimental unit for the calculation of the fertilization rates $(\mathrm{FR}, \%=$ number of dividing eggs $\mathrm{x}$ $100 /$ total number of eggs). After the birth of the larvae, the hatching rates were calculated $(\mathrm{HR}, \%=$ number of hatched larvae x 100/total number of eggs), considering the percentage of the number of normal larvae $(\mathrm{Ln}=$ number of normal larvae x 100/total number of larvae) and the number of abnormal larvae (deformities of the spine and tail).

Nine hundred $S$. parahybae normal larvae (one day after hatching $=1$ dah) derived from extruded females at different ATUs (180, 240 and 300 degree-hours) were selected in 2012. Hatching occurred approximately 11 hours after fertilization, and the larvae were constantly observed under a stereomicroscope until the moment of mouth opening. The larvae were distributed in a completely randomized experimental design with three replicates (in triplicate). Each experimental unit was composed of a 5 liter white tray $(43.0 \times 29.0 \times 4.5 \mathrm{~cm})$ containing 100 larvae each $(20$ larvae/liter), with initial mean length and weight of $7.25 \pm 0.32 \mathrm{~mm}$ and $35.47 \pm 3.23 \mathrm{mg}$, respectively.
Table 2 Experimental design of Steindachneridion parahybae females with regard to accumulated thermal units (ATUs), in both cycles-2011 and 2012

\begin{tabular}{|c|c|c|c|c|c|c|c|c|c|c|}
\hline \multirow[t]{2}{*}{ Groups } & \multirow[t]{2}{*}{ Females } & \multicolumn{9}{|c|}{ Accumulated thermal units-ATUs (degree-hours) } \\
\hline & & 140 & 160 & 180 & 200 & 220 & 240 & 260 & 280 & 300 \\
\hline \multirow[t]{3}{*}{ I } & 1 & XYc & - & - & XYs & - & - & XYs & - & - \\
\hline & 2 & $\mathrm{XYc}$ & - & - & XYs & - & - & XYs & - & - \\
\hline & 3 & XYc & - & - & XYs & - & - & XYs & - & - \\
\hline \multirow[t]{3}{*}{ II } & 4 & - & XYc & - & - & XYs & - & - & Ys & - \\
\hline & 5 & - & XYc & - & - & XYs & - & - & Ys & - \\
\hline & 6 & - & XYc & - & - & XYs & - & - & Ys & - \\
\hline \multirow[t]{3}{*}{ III } & 7 & - & - & XYs & - & - & XYs & - & - & Ys \\
\hline & 8 & - & - & XYs & - & - & XYs & - & - & Ys \\
\hline & 9 & - & - & XYs & - & - & XYs & - & - & Ys \\
\hline
\end{tabular}

$X$ Sample of oocytes/2011; $Y$ sample of oocytes/2012; $X Y c$ first sample of oocytes by cannulation; $X Y s$ first sample of oocytes by stripping 
After the second day of life, with the opening of the mouth, the larvae started eating live food, following a proportion of 120 (second day), 300 (third and fourth days), 600 (fifth to eighth day) and 1200 Artemia salina nauplii per larva (ninth to 15th day), offered at 0900 hours, 1200 hours, 1500 hours, 1800 hours, 2100 hours and 0000 hours. The cysts of Artemia were incubated every two days, in $10 \mathrm{~L}$ transparent hatcheries. The estimate of the nauplii was carried out using the mean quantification of three aliquots of $1 \mathrm{~mL}$ collected from the hatcheries, which were evaluated and counted under a stereomicroscope. That procedure was performed at each feeding. The containers were subjected to a continuous flow of water, suspended only at the moment of feeding (15 min). Siphoning was performed every two days for the removal of waste and leftover food.

Morphometry. Two larvae were removed from each container (six larvae/treatment) every two days, and 10 larvae from each tray (30 larvae/treatment) at the end of the experiment. These larvae were photographed (NIKON Eclipse E-501 microscope) for the analysis of the development of the body structures and then fixed in $10 \%$ formalin. To standardize the minor variations in the size and weight of the $S$. parahybae larvae, the body parameters were established according to Pedreira et al. (2008), where the larvae were individually dried with filter paper, weighed on an analytical balance (accurate to $0.1 \mathrm{mg}$ ), and the length was measured with the aid of a stereomicroscope (Magnification 20x). At the end of the experiment, the final weight, final length and daily weight gain were evaluated.

Larvae survival was obtained by the ratio between the number of larvae used at the beginning of culture and the remaining larvae found at the end of the experiment, as described: $\mathrm{S}=(\mathrm{Ne} / \mathrm{Nb}-\mathrm{Ns})$ x $100[\mathrm{~S}=$ Survival $(\%)$; $\mathrm{Nb}=$ Number of larvae stocked at the beginning of culture; $\mathrm{Ne}=$ Number of larvae removed at the end of culture; Ns $=$ Number of larvae killed for biometry during the experiment].

Statistical analysis. The values of FR, HR and Ln obtained in two samples were submitted to analysis of linear correlation Pearson $5 \%$ significance level. Nonsignificant parameters were removed by the backward stepwise method. The moments the oocytes were collected by stripping in 2011 and 2012 were considered as independent variables. The assumptions were followed as suggested by Myers (1990) and Quinn and Keough (2002). The body parameters of the larvae were submitted to analysis of variance of one factor, one-way ANOVA, at a $5 \%$ level of significance. All the statistical analysis was performed using the Statistica 7.0 Software (Statsoft Inc., NC).

\section{Results}

When the years 2011 and 2012 were compared, only the mean values of $\mathrm{pH}$ of the water in the aquaria exhibited significant differences $(P<0.05)$. The mean values of temperature and dissolved oxygen were similar in both years. However, at the Hydrobiology and Aquaculture Station of the Sao Paulo Energy Company, the mean values of water temperature were relatively lower in the years 2011 and 2012 (Table 3) when compared to previous years. The mean values and standard deviations of the water quality parameters registered in the experimental trays were $22.62 \pm 0.60 \quad\left(\mathrm{~T} \quad{ }^{\circ} \mathrm{C}\right), \quad 7.53 \pm 0.54 \quad(\mathrm{pH}) \quad$ and $7.54 \pm 0.61$ (dissolved oxygen).

Since the percentage distributions of the values of oocyte diameter in the first samples of Steindachneridion parahybae (before the hormonal injection) exhibited similar behavior, they were grouped together and analyzed, highlighting values of $750,1,000,1,100,1,250$ and $1,500 \mu \mathrm{m}$ (Fig. 1). It was evident that the species spawned in batches.

Analyzing the three released batches of Fig. 2a-group $\mathrm{I}$, it is possible to verify one single symmetric mode at $1,500 \mu \mathrm{m}$, independently of the different times (200, 240 and 255 ATU). Clear bimodal distributions of oocyte diameter at 1,500 and 1,600 $\mu \mathrm{m}$ were observed in Fig. 2bgroup II (225, 282 and 300 ATU). In Fig. 2c—group III, a

Table 3 Mean values and standard deviations of the water quality parameters registered in the aquaria and hatcheries during the experimental period

\begin{tabular}{lrrr}
\hline & \multicolumn{1}{l}{ Years } & \multirow{2}{*}{$P$ value* } \\
\cline { 2 - 3 } Parameters & January 2011 & January 2012 & \\
\hline Water temperature $\left({ }^{\circ} \mathrm{C}\right)$ & $22.34 \pm 0.53$ & $21.88 \pm 0.15$ & 0.1082 \\
pH & $6.88 \pm 0.10$ & $6.10 \pm 0.10$ & 0.0029 \\
Dissolved oxygen $(\mathrm{mg} / \mathrm{L})$ & $5.10 \pm 0.61$ & $5.97 \pm 1.53$ & 0.2986 \\
\hline
\end{tabular}

* Mann-Whitney nonparametric test

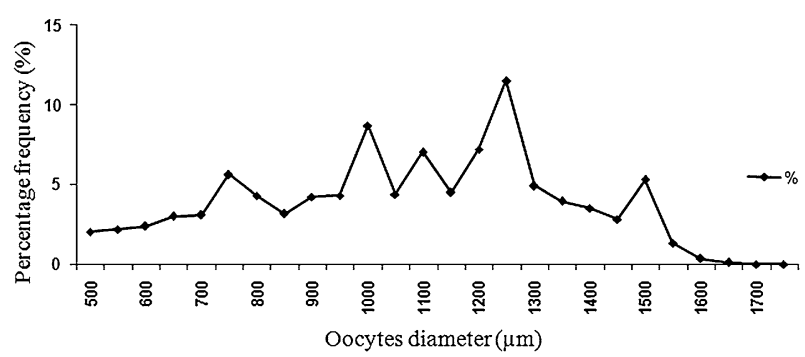

Fig. 1 Percentage frequency distribution of Steindachneridion parahybae oocytes diameter, before the first hormonal injection $(n=18)$, in both reproductive cycles 
Fig. 2 Percentage frequency distribution of

Steindachneridion parahybae oocytes diameter at different times. (a) Group I, (b) Group II and (c) Group III. ATU

Accumulated thermal unit

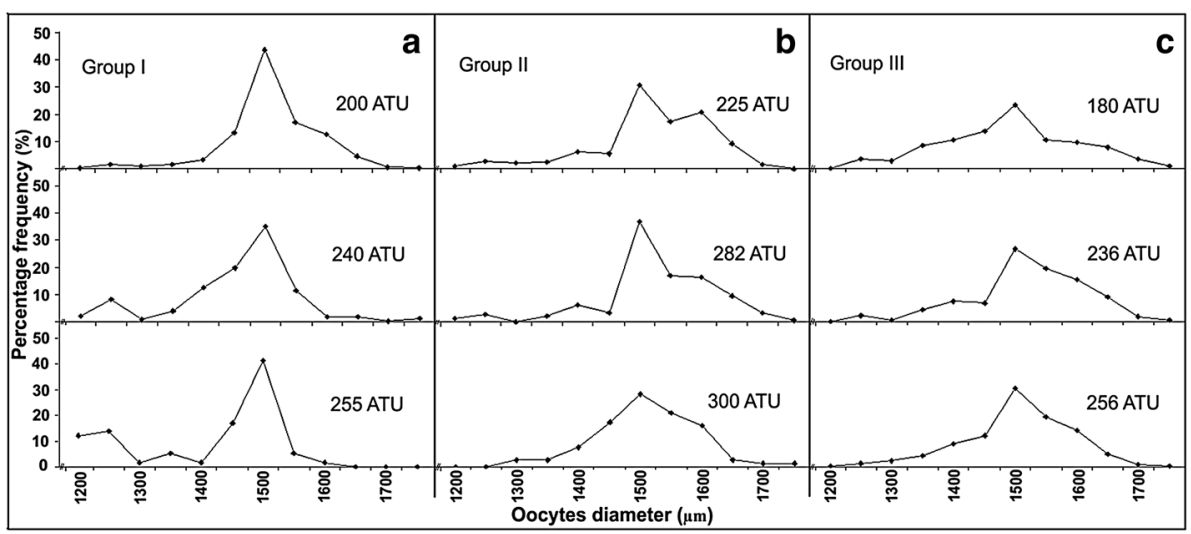

reduction in the values of percentage frequency is observed, showing signs of oocytes in ovarian regression.

However, it is curious that for the genus Steindachneridion this process of closure of the blastoporus is slow: in $S$. parahybae, it occurred 11 hours after fertilization, at $22.12 \pm 0.33{ }^{\circ} \mathrm{C}$.

The linear effect $(P<0.05)$ was observed in 2011 for the fertilization rates (Fig. 3a) and hatching rates (Fig. 3b). Nonetheless, in 2012 the quadratic effect $(P<0.05)$ was observed for the fertilization rates (Fig. 3c), hatching rates (Fig. 3d) and normal larvae (Fig. 3e).

At first, oocyte release (stripping) occurred according to protocol; one of the females, however, anticipated the release of oocytes (174.2 degree-hours), showing then the highest values of fertilization rates $(84.22 \%)$ obtained in 2011 (Fig. 3a). In 2012, the highest values of fertilization rates $(55.58 \%)$ were verified at 251 degree-hours (Fig. 3c).

A negative linear trend can be noticed in Fig. $3 \mathrm{a}$, as the ATUs increased.

In 2011, the highest values of hatching rates $(71.33 \%)$ were found at 174.2 degree-hours (Fig. 3b). In 2012, the highest values of hatching rates $(36.13 \%)$ were observed at 251 degree-hours (Fig. 3d).

In 2011, a significant effect with regard to the percentage of normal larvae $(\mathrm{Ln}=86.42 \%$ at 174.2 degreehours) was not observed. However, in 2012 the mean value of normal S. parahybae larvae found at 251 degree-hours was $86.31 \%$ (Fig. 3e).

Fig. 4 shows the beginning of exogenous feeding and development of the digestive tract, with the mouth (Fig. 4a) and anus opening (Fig. 4b) of the larvae of $S$. parahybae, two days after hatching (2dah).

After the mouth opening, the larvae of $S$. parahybae started consumption of nauplii 2 days after hatching (2dah), and the complete absorption of the yolk sac was visible 5 days after hatching (5dah), when the larvae exhibited a mean total length of $9.19 \pm 0.30 \mathrm{~mm}$ and mean weight of $75.83 \pm 12.10 \mathrm{mg}$. During the feed management performed in the present study, it was observed that the larvae remained preferably at the bottom or adjacent to the walls of the containers, as well as the nauplii, facilitating capture by the larvae.

In Fig. 4, it is possible to observe Artemia nauplii in the stomach (Fig. 4c), as well as the heart and gill rakers (Fig. 4d) in the larvae of $S$. parahybae, five days after hatching. In the present study, the larvae of S. parahybae accepted feeding with Artemia nauplii very well. Intraspecific cannibalism was observed during the experiment.

\section{Discussion}

The history of Steindachneridion parahybae migration in and out of the reproductive period is virtually unknown. Recent investigations about its reproduction in captivity indicate that the species exhibits parceled spawning, with heterogeneous populations of developing oocytes released on several occasions of the reproductive period, differentiating it from other species of the same genus such as Steindachneridion melanodermatum (see Ludwig et al. 2005) and Steindachneridion scriptum (see Zaniboni-Filho et al. 2010), which exhibit total spawning.

A constant evaluation of the females is necessary because the delay in the release may cause "regressed" (Fig. 2c), "supermature or overripe" oocytes (Romagosa 2010). The reduction in the values of percentage frequency was verified in one of the groups (Fig. 2c-group III), showing evidence of oocytes in ovarian regression, similar to those described by Leonardo et al. (2006) for Pseudoplatystoma fasciatum. According to Zaniboni-Filho and Nuñer (2004), the process, also known as follicular atresia, may affect the reproductive performance in fish, especially the fertilization and hatching rates.

The study of the percentage frequency distribution of oocyte diameter allows the evaluation of the degree of 
Fig. 3 Mean values of the fertilization rates $(\mathbf{a}, \mathbf{c})$, hatching rates $(\mathbf{b}, \mathbf{d})$ and number of normal larvae (e) of Steindachneridion parahybae in 2011 and 2012
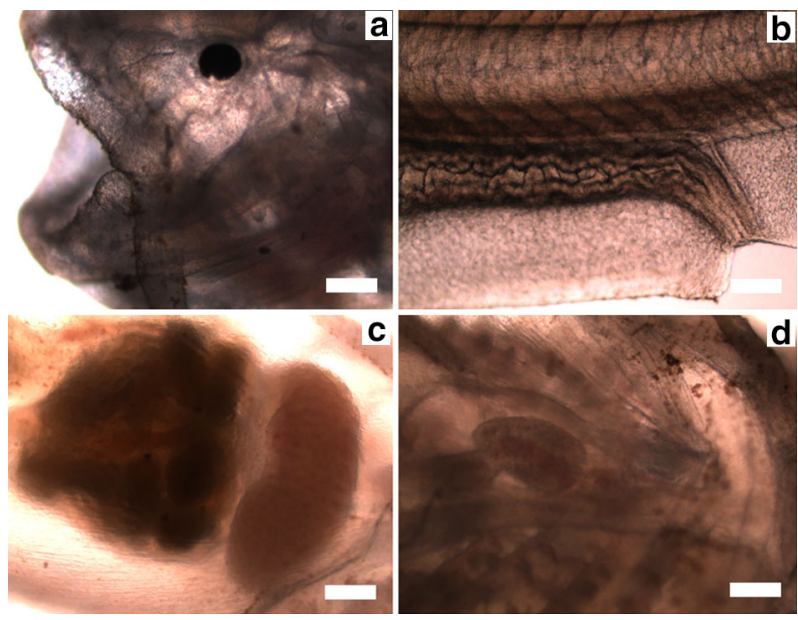

Fig. 4 Beginning of exogenous feeding and development of the digestive tract, with mouth (a) and anus opening (b); the presence of Artemia salina nauplii in the stomach contents (c); heart and development of the gill rakers (d) in larvae of Steindachneridion parahybae. Scale bars $0.1 \mathrm{~mm}$
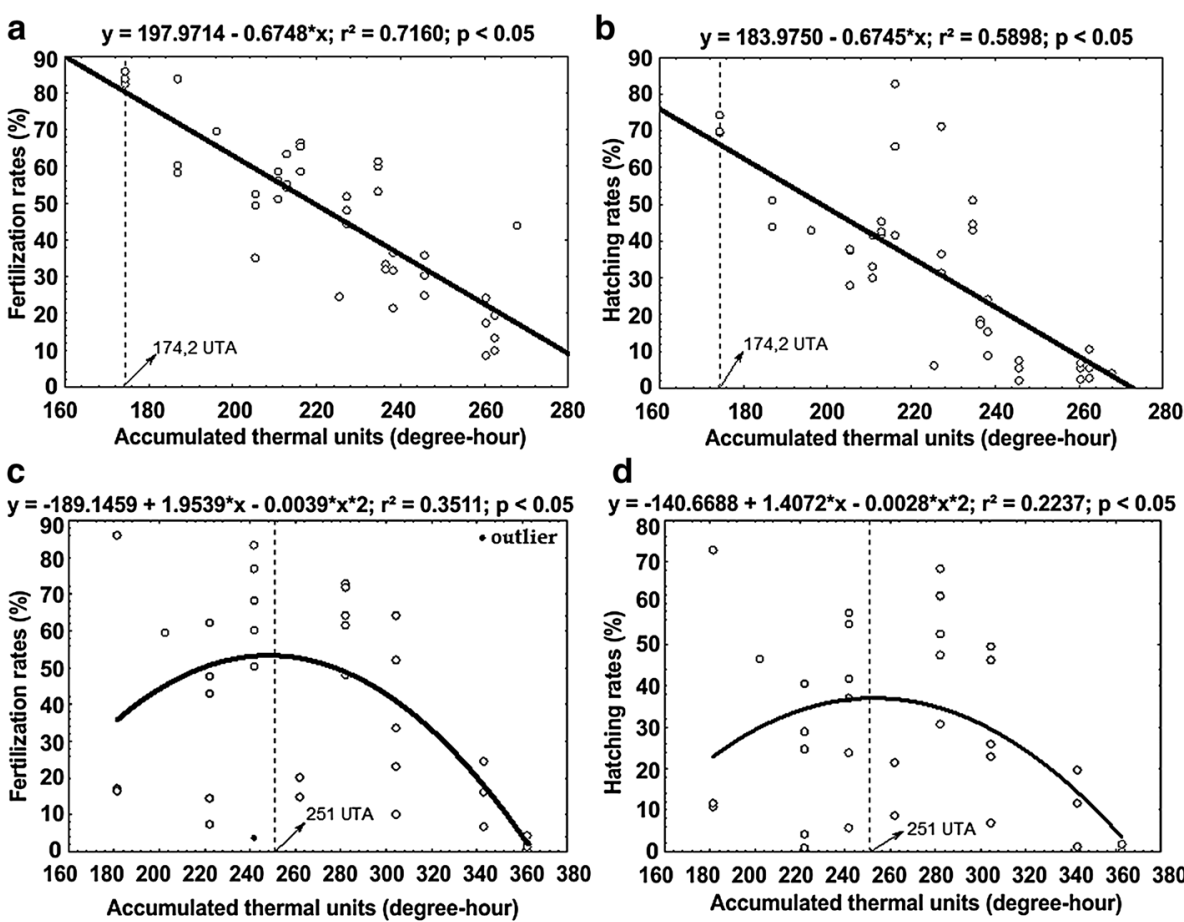

$y=-140.6688+1.4072^{\star} x-0.0028^{\star} x^{\star} 2 ; r^{2}=0.2237 ; p<0.05$

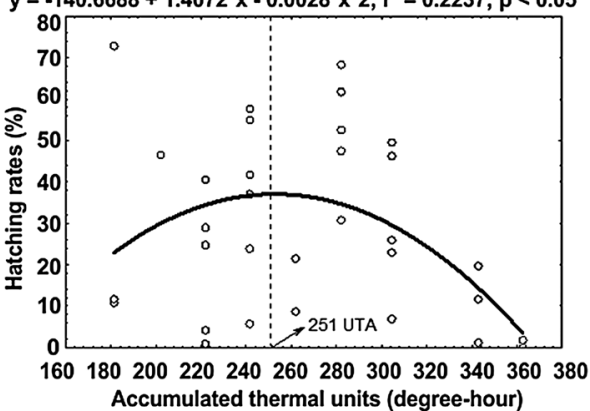

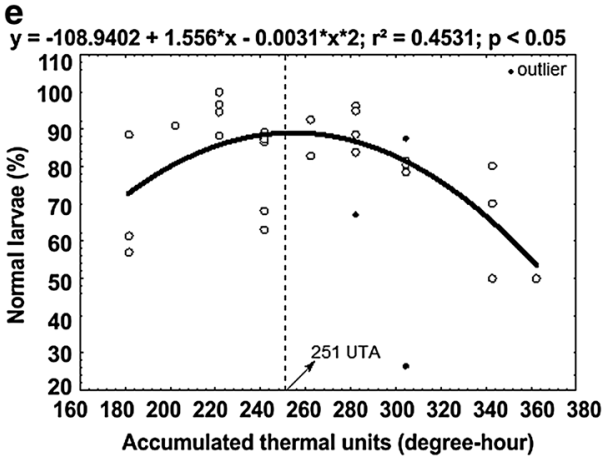

ovarian development of native fish such as Piaractus mesopotamicus (see Romagosa et al. 1990), Brycon insignis (see Andrade-Talmelli et al. 2002), Brycon cephalus (see Romagosa et al. 2001), Pseudoplatystoma fasciatum (see Leonardo et al. 2004), S. melanodermatum (see ZaniboniFilho et al. 2010) and Rhamdia quelen (see Amorim et al. 2009).

In water quality, both the $\mathrm{pH}$ and the dissolved oxygen values were suitable for the culture of this species (Table 3). These requirements were similar to those observed in other catfish, such as jundiá, Rhamdia quelen, and pintado, Pseudoplatystoma corruscans (see Zaniboni-Filho et al. 2010), whose values remained within the limits determined for aquaculture (CONAMA 2005).

In this study, the estimate of the fertilization rate was carried out after the closure of the blastoporus, as recommended by Bobe and Labbé (2010). However, it is curious that for the genus Steindachneridion this process is slow: in $S$. parahybae it occurred 11 hours after fertilization at 
$22.12 \pm 0.33{ }^{\circ} \mathrm{C}$, and in $S$. scriptum eight hours and fortyfive minutes after fertilization (at $25.1{ }^{\circ} \mathrm{C}$ ) (Zaniboni-Filho et al. 2010). Differently from other Pimelodidae, Pseudoplatystoma corruscans exhibited closure of the blastoporus six hours after fertilization between 23.5 and $25.5{ }^{\circ} \mathrm{C}$ (Cardoso et al. 1995). Studying other species of the order Siluriformes, Sato et al. (2003) performed the stripping of Pseudoplatystoma sp. oocytes at $226 \pm 4$ degree-hours, at a temperature of $24.3 \pm 0.7{ }^{\circ} \mathrm{C}$, but Smerman et al. (2002) obtained values lower than 200 ATUs, at a mean temperature of $27.31 \pm 0.72{ }^{\circ} \mathrm{C}$ for the same species. Differences between the accumulated thermal units were described for Rhinelepis aspera, at 212 ATUs, at a mean temperature of $25.8 \pm 0.4{ }^{\circ} \mathrm{C}$ (López, unpublished data) and Rhamdia quelen, in a range from 220 to 240 degreehours, at $22-27{ }^{\circ} \mathrm{C}$ (Baldisserotto et al. 2010).

For the genus Steindachneridion, it was verified that the release of $S$. melanodermatum oocytes occurred at $260 \pm 20$ ATUs, at $27{ }^{\circ} \mathrm{C}$ (Ludwig et al. 2005). However, with $S$. scriptum oocytes, lower values were observed: $155 \pm 26$ degree-hours, at $23{ }^{\circ} \mathrm{C}$ (Zaniboni-Filho et al. 2010). For $S$. parahybae, Caneppele et al. (2009) verified oocyte release at 240 and 255 ATUs at $24{ }^{\circ} \mathrm{C}$ in the same study site.

The absorption of the yolk sac is vital for the larva, because at that stage the still rudimentary digestive system is in the process of differentiation (Lopes et al. 1994), and in many fish species most organs begin to be functional after the first feeding and during the differentiation of the larval stages and metamorphosis (Godinho et al. 2003; Santos et al. 2013). In S. scriptum, the larvae stop absorbing the yolk sac with mean total length of $8.6 \pm 0.42 \mathrm{~mm}$ and weight of $7.7 \pm 1.4 \mathrm{mg}$, developing cannibal behavior from that period on (Adamante et al. 2007). Feiden et al. (2005), studying S. melanodermatum, observed such absorption and intense cannibalism when the larvae exhibited mean total length of $8.35 \pm 0.85 \mathrm{~mm}$ and weight of $6.75 \pm 0.64 \mathrm{mg}$. For $P$. corruscans, the complete absorption of the yolk sac reserves was verified on the fifth day of life (Santos and Godinho 1994) and 60 hours after hatching (Landines et al. 2003), indicating that the water temperature has an important effect on the metabolism, accelerating or retarding the time of each larval stage (Table 4).

The knowledge of feeding behavior, prey preferences, even as the yolk sack absorption and mouth opening (which varies among species) will determine the requirements for exogenous food during larval growth (Appelbaum and Mcgeer 1998). According to Behr (personal communication) and Luz and Portella (2005), the use of Artemia sp. nauplii at the beginning of exogenous feeding is common, because it provides satisfactory results, with easy laboratory production. Artemia sp. has a high nutritional value, with high level of protein and a suitable composition of amino acids. Nevertheless, since Artemia sp. is a saltwater organism, it has a limited lifetime in freshwater, a fact that causes the mortality of nauplii and may cause problems of water quality (decomposition), as well as limit the time of exposure of the live food to the larvae (Luz and Portella 2002).

For the same species, S. parahybae, Honji et al. (2012) observed the same behavior of cannibalism. Although the species has exhibited high survival rates $(\geq 63 \%)$ when compared to other species of the family Pimelodidae, the high percentage of survival is due to the abundant supply of live food (six times/day). Behr (personal communication), feeding Pseudoplatystoma corruscans larvae solely on Artemia nauplii, obtained survival rates of $65.6 \%$ on the ninth day of the experiment, at densities of 10 larvae/liter. Similar results were found on the tenth day of the experiment, with survival rates of $70.29 \%$, mean weight and length of $4.76 \pm 0.21 \mathrm{mg}$ and $15.2 \pm 0.29 \mathrm{~mm}$, respectively, at an estimated density of 50 larvae/liter (Marinho, personal communication). Feiden et al. (2006), measuring S. melanodermatum larvae fed on Artemia salina at a density of 0.4 larvae/liter, obtained a final length of $36.0 \pm 0.9 \mathrm{~mm}$, final weight of $446 \pm 37.7 \mathrm{mg}$ and survival of $75 \pm 6.4 \%$ in a period of 28 days. Adamante et al. (2007), feeding S. scriptum larvae in a period of eight days, at a density of 10 larvae/liter, obtained a final weight, final length and survival of $31.8 \pm 8.8 \mathrm{mg}, 13.8 \pm 1.0 \mathrm{~mm}$ and $53.3 \pm 20.4 \%$, respectively.
Table 4 Mean values and standard deviations of the body parameters of Steindachneridion parahybae larvae fed on Artemia salina nauplii for 15 days

\begin{tabular}{lccrl}
\hline Parameters & \multicolumn{2}{l}{ Accumulated thermal units-ATUs (degree-hours) } & \multirow{2}{*}{$P$ value } \\
\cline { 2 - 4 } & \multicolumn{1}{c}{ 180 } & \multicolumn{1}{l}{300} & \\
\hline Initial weight (mg) & $39.20 \pm 5.87$ & $33.50 \pm 5.34$ & $33.70 \pm 6.75$ & n.a. \\
Final weigth (mg) & $523.67 \pm 54.42$ & $496.67 \pm 61.98$ & $475.00 \pm 2.83$ & 0.6125 \\
Weight gain (mg) & $484.47 \pm 54.42$ & $463.17 \pm 61.98$ & $441.30 \pm 2.83$ & 0.6804 \\
Initial length (mm) & $7.54 \pm 0.28$ & $6.91 \pm 0.30$ & $7.30 \pm 0.26$ & n.a. \\
Final length (mm) & $17.75 \pm 0.57$ & $17.58 \pm 0.51$ & $17.45 \pm 0.25$ & 0.7885 \\
Survival (\%) & $63.95 \pm 24.50$ & $71.71 \pm 6.61$ & $79.65 \pm 0.82$ & 0.5928 \\
\hline
\end{tabular}


According to Nowosad et al. (2014), the efficiency of actions which aim to protect endangered species depends on how well the species biology has been elucidated. So, it is important to determine the optimum temperature ranges and to perfect techniques of fish reproduction under changing conditions, notably climate change. Therefore, the estimate of the accumulated thermal units allows us to reduce the handling of the broodfish, reflecting in the productive performance of the eggs and larvae (Ceccarelli et al. 2000).

In short, the present study aimed to generate essential information for the conservation of the diversity of a unique fish fauna. The variation of the degree-hours shows that it is necessary to investigate the interrelationships (ovulation $\mathrm{x}$ ATUs) more deeply, with the objective of increasing the fertilization, hatching and larvae survival rates, contributing to the conservation of the species.

Acknowledgements We are thankful to the Sao Paulo Energy Company (CESP) for the opportunity of developing this study. This study was supported by grants from and the Sao Paulo Research Foundation (FAPESP) (2011/04780-5 and 2011/02818-5).

\section{References}

Adamante WB, Weingartner M, Nuñer APO (2007) Feed transition in larval rearing of bocudo, Steindachneridion scripta (Pisces, Pimelodidae), using Artemia spp. nauplii and artificial diet. Arq Bras Med Vet Zootec 59:1294-1300

Amorim MP, Gomes BVC, Martins YS, Sato Y, Rizzo E, Bazzoli N (2009) Early development of the silver catfish Rhamdia quelen (Quoy \& Gaimard, 1824) (Pisces: Heptapteridae) from the São Francisco River Basin, Brazil. Aquacult Res 40:172-80

Andrade-Talmelli EF, Kavamoto ET, Narahara MY, Fenerich-Verani N (2002) Reprodução induzida da piabanha, Brycon insignis (Steindachner, 1876), mantida em cativeiro. $\mathrm{R}$ Bras Zootec 31:803-811

Appelbaum S, Mcgeer JC (1998) Effect of diet and light regime on growth and survival of African catfish (Clarias gariepinus) larvae and early juveniles. Aquacult Res 4:157-164

Baldisserotto B, Neto JR, Barcellos LG (2010) Jundiá (Rhamdia sp.). In: Baldisserotto B, Gomes LC (eds) Espécies nativas para piscicultura no Brasil. Editora da UFSM, Santa Maria, pp 301-333

Bobe J, Labbé C (2010) Egg and sperm quality in fish. Gen Comp Endocrinol 165:535-548

Brooks S, Tyler CR, Sumpter JP (1997) Egg quality in fish: what makes a good egg? Rev Fish Biol Fisher 7:387-416

Caneppele D, Honji RM, Hilsdorf AWS, Moreira RG (2009) Induced spawning of the endangered Neotropical species Steindachneridion parahybae (Siluriformes: Pimelodidae). Neotrop Ichthyol 7:759-762

Cardoso EL, Alves MSD, Ferreira RMA, Godinho HP (1995) Embryogenesis of the neotropical freshwater Siluriformes Pseudoplatystoma corruscans. Aquat Living Resour 8:343-346

Ceccarelli PS, Senhorini JA, Volpato GL (2000) Dicas em piscicultura; perguntas e respostas. Editora Santa Gráfica, Botucatu

CONAMA (2005) Resolução $n^{\circ}$ 357. Dispõe sobre a classificação dos corpos de água e diretrizes ambientais para o seu enquadramento. Conselho Nacional de Meio Ambiente. MMA. http://www.mma.gov.br/port/conama. Accessed 17 March 2005

Feiden A, Hayashi C, Boscolo WR, Signor A (2005) Desenvolvimento do Surubim-do-iguaçu (Steindachneridion sp.) Garavello (1991) (Siluriforme: Pimelodidae) em ambiente escuro durante a fase inicial, alimentado com diferentes dietas. Semina Ci Agr. 26:109-116

Feiden A, Hayashi, C, Boscolo WR (2006) Desenvolvimento de larvas de surubim-do-iguaçu (Steindachneridion melanodermatum) submetidas a diferentes dietas. $\mathrm{R}$ Bras Zootec 35:2203-2210

Gadomski DM, Caddell SM (1996) Effect of temperature on the development and survival of eggs of four coastal California fishes. Fish Bull 94:41-48

Godinho HP, Santos JE, Sato Y (2003) Ontogênese larval de cinco espécies do São Francisco. In: Godinho HP, Godinho AL (eds) Àguas, peixes e pescadores do São Francisco das Minas Gerais. Editora PUC Minas, Belo Horizonte, pp 133-148

Hilder ML, Pankhurst NW (2003) Evidence that temperature change cues reproductive development in the spiny damselfish, Acanthochromis polyacanthus. Environ Biol Fish 66:187-196

Hilsdorf AWS, Petrere M (2002) Conservação de peixes na bacia do rio Paraíba do Sul. Ci Hoje 30:62-65

Honji RM, Tolussi CE, Mello PH, Caneppele D, Moreira RG (2012) Embryonic development and larval stages of Steindachneridion parahybae (Siluriformes: Pimelodidae) - implications for the conservation and rearing of this endangered Neotropical species. Neotrop Ichthyol 10:313-327

King HR, Pankhurst NW, Watts M, Pankhurst PM (2003) Effect of elevated summer temperatures on gonadal steroid production, vitellogenesis and egg quality in female Atlantic salmon. J Fish Biol 63:153-167

Kucharczyk D, Zarski D, Targonska K, Luczynski MJ, Szczerbowski A, Nowosad J, Kujawa R, Mamcarz A (2014) Induced artificial androgenesis in common tench, Tinca tinca (L), using common carp and common bream eggs. Ital J Anim Sci 13:196-200

Kujawa R, Kucharczyk D, Mamcarz A (1997) Effect of temperature on embryonic development of asp (Aspius aspius L). Pol Arch Hydrobiol 44:139-143

Kupren K, Mamcarz A, Kucharczyk D (2011) Effect of variable and constant thermal conditions on embryonic and early larval development of fish from the genus Leuciscus (Cyprinidae, Teleostei). Czech J Anim Sci 56:70-80

Landines MA (2003) Efeito da triiodotironina (T3) no desenvolvimento embrionário e no desempenho das larvas de pintado (Pseudoplatystoma coruscans), piracanjuba (Brycon orbignyanus) e dourado (Salminus maxillosus). Ph. D. Dissertation. Universidade Estadual Paulista, Jaboticabal, São Paulo, Brasil

Landines MA, Senhorini JA, Sanabria AI, Urbinati EC (2003) Desenvolvimento embrionário do pintado, Pseudoplatystoma corruscans (Agassiz, 1829). Bol Téc CEPTA 16:1-13

Leonardo AFG, Romagosa E, Batlouni SR, Borella MI (2004) Induced spawning of hatchery-raised Brazilian catfish, cachara Pseudoplatystoma fasciatum (Linnaes, 1766). Aquaculture 240:451-461

Leonardo AFG, Romagosa E, Batlouni SR (2006) Ocorrência e importância da regressão ovariana e folicular em cacharas, Pseudoplatystoma fasciatum (Linnaeus, 1766). Enfoque histológico. Arq Bras Med Vet Zootec 58:831-840

Lopes RNM, Senhorini JA, Soares MCF (1994) Crescimento e sobrevivência de larvas de matrinxã Brycon cephalus Gunther, 1869, (Pisces, Characidae) sob diferentes dietas alimentares. Bol Téc CEPTA7:41-48

Ludwig LAM, Gomes E, Artoni RF (2005) Um método de reprodução induzida para o surubim Steindachneridion melanodermatum 
(Siluriformes, Pimelodidae) do rio Iguaçu. Ci Biol Saúde 11:23-27

Luz RK, Portella MC (2002) Larvicultura de trairão (Hoplias lacerdae) em água doce e água salinizada. $\mathrm{R}$ Bras Zootec 31:829-834

Luz RK, Portella MC (2005) Freqüência alimentar na larvicultura de trairão (Hoplias lacerdae). R Bras Zootec 34:1442-1448

Machado CEM, Abreu HCF (1952) Notas preliminares sobre a caça e a pesca no Estado de São Paulo. A pesca no Vale do Paraíba. Bol Ind Anim 13:145-160

Ministério do Meio Ambiente - MMA (2008) Livro Vermelho da Fauna Ameaçada de Extinção. In: Machado ABM, Drummond GM, Paglia AP (Eds.) $-1^{\mathrm{a}}$ ed - Brasília, Goiás

Myers RH (1990) Classical and modern regression with applications, second ed. Duxbury press, Belmont, California

Nowosad J, Targonska K, Chwaluczyk R, Kaszubowski R, Kucharczyk D (2014) Effect of temperature on the effectiveness of artificial reproduction of dace [Cyprinidae (Leuciscus leuciscus (L.))] under laboratory and field conditions. J Thermal Biol 45:62-68

Pedreira MM, Santos JCE, Sampaio EV, Silva JL, Ferreira FN (2008) Fontes de erros na mensuração do comprimento e peso de larvas de peixes. Acta Scientiarum Biol Sci 30:245-251

Quinn GP, Keough MJ (2002) Experimental design and data analysis for biologists. Cambridge University Press, New York, New York

Romagosa E, Paiva P, Godinho HM (1990) Pattern of oocyte diameter frequency distribution in females of the pacu, Piaractus mesopotamicus (Holmberg, 1887) (Colossoma mitrei Berg, 1895 ) induced to spawn. Aquaculture 86:105-110

Romagosa E, Narahara MY, Borella MI, Fenerich-Verani N (2001) Seleção e caracterização de fêmeas de matrinxã, Brycon cephalus, induzidas a reprodução. Bol Inst Pesca 27:113-121

Romagosa E (2010) Reproductive status in females of the Brazilian catfish, Pseudoplatystoma fasciatum reared in cages. J Appl Ichthyol 26:806-811

Rosa RS, Lima FCT (2005) Peixes. In: Machado AB, Martins CS, Drummond GM (eds) Livro vermelho da fauna brasileira ameaçada de extinção. Biodiversitas, Belo Horizonte
Sanches EA, Bombardelli RA, Baggio DM, Souza BE (2009) Dose inseminante para fertilização artificial de ovócitos de dourado. R Bras Zootec 38:2091-2098

Santos JE, Godinho HP (1994) Morfogênese e comportamento larvais do surubim, Pseudoplatystoma corruscans, sob condições experimentais. Arq Bras Med Vet Zootec 46:139-147

Santos HB, Arantes FP, Samapaio EV, Sato H (2013) Artificial reproduction and reproductive parmeters of the internally inseminates driftwood catfish Trachelyopterus galeatus (Siluriformes: Auchenipteridae). Ichthyol Res 60:142-148

Sato Y, Fenerich-Verani N, Nuñer APO, Godinho HP, Verani JR (2003) Padrões reprodutivos de peixes da bacia do São Francisco. In: Godinho HP, Godinho AL (eds) Águas, peixes e pescadores do São Francisco das Minas Gerais. PUC Minas, Belo Horizonte

Simpson AC (1951) The fecundity of the plaice. Fish Invest 17:1-27

Smerman W, Castro JG.D, Toledo JJ, Rosa CAS, Godoi DS (2002) Larvicultura de Pintado (Pseudoplatystoma sp.) em Alta Floresta - Mato Grosso. R Biol Ci Terra 2:1-8

Van Zutphen, LFM, Baumans V, Beynen AC (2001) Principles of Laboratory Animal Science - A contribution to the humane use and care of animals and to the quality of experimental results, revised edition. Elsevier, Amsterdam

Vikingstad E, Andersson E, Norberg B, Mayer I, Klenke U, Zoher Y, Stefansson SO, Taranger GL (2008) The combined effects of temperature and GnRHa treatment on the final stages of sexual maturation in Atlantic salmon (Salmo salar L). Fish Physiol Biochem 34:289-298

Zaniboni-Filho E, Nuñer APO (2004) Fisiologia da reprodução e propagação artificial dos peixes. In: Cyrino JEP, Urbinati EC, Fracalossi DM, Castagnolli N (eds) Tópicos especiais em piscicultura de água doce. Editora TecArt, Jaboticabal, pp 45-73

Zaniboni-Filho E, Reynalte-Tataje D, Hermes-Silva S (2010) Cultivo de bagres do gênero Steindachneridion. In: Baldisserotto B, Gomes LC (eds) Espécies nativas para piscicultura no Brasil. Editora da UFSM, Santa Maria, pp 363-378 